\title{
Heat treatment and active packaging to improve the storage of fresh-cut melons (Cucumis melo L.)
}

\author{
Cristiane Maria A. Morgado ${ }^{1,2, \star}$, Huguette Sallanon ${ }^{1}$, Ben-Hur Mattiuz ${ }^{2}$, Phrutiya Nilprapruck ${ }^{1}$ \\ and Florence Charles ${ }^{1}$ \\ 1 Université d'Avignon et des Pays de Vaucluse, Laboratoire Physiologie des Fruits et Légumes - UMR Qualisud, F-84018 Avignon, France \\ 2 Universidade Estadual Paulista "Julio de Mesquita Filho", Departamento de Tecnologia, Jaboticabal, São Paulo, Brazil
}

Received 20 March 2015 - Accepted 9 September 2015

\begin{abstract}
Introduction. Melon (Cucumis melo L.) is highly appreciated by consumers due to its sensory attributes and nutritional content. Producing minimally processed fruit has potential, because consumers look for freshness and convenience. However, fresh-cut processing increases the contact enzymes and their respective substrates because the cell tissue rupture, and this causes browning, softening and decay. This study investigated the effect of a combination of heat treatment with active modified atmosphere packaging on the quality of fresh-cut melons. Materials and methods. Whole 'Charentais' melon fruits were dipped in hot water (at $50{ }^{\circ} \mathrm{C}$ for $30 \mathrm{~min}$ ), cooled, minimally processed and packaged in traditional polymeric film (oriented polypropylene, OPP) or biodegradable film (polylactic acid, PLA) with an initial flush of a gas mixture composed of $2-3 \% \mathrm{O}_{2}$ and $7-8 \% \mathrm{CO}_{2}$. The quality of the fresh-cut melons was monitored for 11 days after treatment. Results and discussion. Gas changes demonstrated that (i) PLA permeability was higher than OPP permeability, and (ii) the heat treatment could temporarily reduce the respiration rate of fresh-cut melons. Heat treatment as a stress could also increase the beta-carotene content. Conclusion. The combination of heat treatment and active MAP with OPP film significantly improved both the decay development and the visual quality of fresh-cut melons for up to 11 days.
\end{abstract}

Keywords: melon / Cucumis melo / respiration rate / fruit quality trait / fresh-cut fruit / modified atmosphere packaging / biodegradable film Résumé - Un traitement thermique associé aux emballages actifs améliore la conservation des melons (Cucumis
melo L.) frais découpés. Introduction. Le melon (Cucumis melo L.) est très apprécié des consommateurs en raison de
ses caractéristiques sensorielles et de son contenu nutritionnel. La production de fruits peu transformés a un fort débou-
ché, parce que les consommateurs recherchent la fraîcheur et la commodité des produits. Cependant, la découpe en frais
augmente le contact des enzymes et leurs substrats, ce qui provoque brunissement, ramollissement et pourrissement du
fruit. Ce travail a étudié l'effet de la combinaison d'un traitement thermique avec un conditionnement sous atmosphère
modifiée (MAP) sur la qualité des melons frais découpés. Matériel et méthodes. Des melons charentais entiers ont été
plongés dans l'eau chaude (à $50^{\circ} \mathrm{C}$ pendant 30 min), refroidis, légèrement transformés puis emballés dans un film po-
lymère traditionnel (polypropylène orienté, OPP) ou dans un film biodégradable (acide polylactique, PLA) en présence
d'un mélange gazeux initial composé de $2-3 \%$ O 2 et $7-8 \%$ CO2. La qualité des melons frais découpés a été suivie
pendant 11 jours après traitement. Résultats et discussion. Les changements de composition gazeuse ont montré que :
(i) la perméabilité membranaire du PLA était plus élevée que celle du OPP, (ii) le traitement thermique pouvait réduire
de façon momentanée la fréquence respiratoire des melons frais coupés. Le stress provoqué par le traitement thermique
pouvait aussi augmenter la teneur en bêta-carotène. Conclusion. Le traitement thermique combiné au MAP actif avec
le film OPP a considérablement amélioré le vieillissement et de la qualité visuelle des melons frais découpés jusqu'à
11 jours.

Mots clés : melon / Cucumis melo / conditionnement sous atmosphère modifiée / film biodégradable / fréquence respiratoire / qualité du fruit / quatrième-gamme

^ Corresponding author: cristianemorgado4@yahoo.com.br 


\section{Introduction}

Melons (Cucumis melo L.) belong to the family Cucurbitaceae. The fruit contains about $90 \%$ water besides minerals, and vitamins $\mathrm{C}, \mathrm{E}$ and $\mathrm{A}$, the latter mainly in fruits with orange pulp, due to the presence of $\beta$-carotene. These characteristics make this fruit appreciated by consumers, who do not choose melons mainly for their nutritional properties, but rather according to the organoleptic properties of the fruit [1]. The 'Charentais' type of melon is of French origin, belongs to the Cantaloupensis group, and has or not a net peel. The peel is light green and the pulp can vary from orange to salmon, this being considered the most refined. These fruits stand out for their strong and pleasant aroma.

Demand for fresh-cut products has been increasing in recent years, mainly because consumers look for freshness and convenience. However, $85 \%$ of the market is represented by fresh-cut salads [2]. Fresh-cut melons have a real potential for the fresh-cut industry. However, rapid deterioration after harvest and during transport and storage is a serious problem. The fresh-cut processing increases the metabolic activity, the contact between enzymes and their respective substrates because of the cell tissue rupture, and this causes browning, softening and decay. Polyphenoloxidase (PPO) and peroxidase (POD) are the main enzymes inducing browning. These oxidizing enzymes react with the plant phenolic compounds to produce quinones, which self-oxidize and polymerize via non-enzymatic mechanisms to produce some insoluble greater complexes, so-called "brown pigments".

Post-harvest techniques such as refrigeration and controlled or modified atmosphere packaging (MAP) are largely used to extend the shelf life of vegetables. MAP consists of the alteration of the $\mathrm{O}_{2}$ and $\mathrm{CO}_{2}$ gaseous environment produced as a result of fruit respiration (passive MAP), or by addition/removal of gas(es) from the food package (active MAP). For fresh-cut products, synthetic polymeric films are the most widely used packaging, such as low-density polyethylene (LDPE) or oriented polypropylene (OPP). However, the extensive use of synthetic packaging films has led to serious ecological problems due to their total non-biodegradability.

Due to environmental recommendations, research on biodegradable films has become essential. Polylactic acid (PLA) film is a biodegradable packaging originating from agricultural sources such as starch and representing a good alternative for food. The growing environmental awareness requires packaging films and processes that have both user-friendly and eco-friendly attributes. As a consequence, biodegradability is not only a functional requirement but also an important environmental attribute. Different packaging materials, differing in water vapor and gas barrier properties, for preserving the quality of dipped and undipped fresh-cut produce were studied by Conte et al. [3], who found that biodegradable films, combined with a dipping pre-treatment, represented a good compromise between film performance and environmental impact.

However, these traditional methods are sometimes not sufficient to increase the storage of fresh-cut fruit. Other physical methods can be proposed such as heat treatment. Applied by hot water, vapor heat or hot air, it can control insect pests, prevent fungal rots and increase resistance to chilling injury [4].
Heat treatments also inhibit fruit ripening and softening and improve the post-harvest quality of whole fruit. This was observed, for instance, in the case of apple [5], strawberries [6], citrus [7], mango [8] and melon [9]. Concerning fresh-cut fruit, heat treatments are mostly applied before processing to delay the ripening and senescence processes. Heating whole melon fruit at $50{ }^{\circ} \mathrm{C}$ for $60 \mathrm{~min}$ improved the fresh-cut produce quality, decreasing both the respiration rate and the moisture loss, and increasing the sweet aromatic flavor [10].

This study intends to combine heat treatment and active MAP to improve the storage of fresh-cut melons and evaluate the process as potential bio-packaging.

\section{Materials and methods}

\subsection{Plant Material}

'Charentais' type melons (Cucumis melo L.) were purchased at a local supermarket in Avignon, southern France, a famous production area, and immediately brought to the laboratory. Fruits were selected for their uniformity (size and color) and absence of visible wounds or infection.

\subsection{Heat treatment and fresh-cut process}

Whole melon fruits were washed in tap water and prepared in two batches: the first one was immersed in a hot water bath for $30 \mathrm{~min}$ at $50{ }^{\circ} \mathrm{C}(\mathrm{HT})$; the second one was used as control (CTRL). Heated fruits were cooled in water at $13{ }^{\circ} \mathrm{C}$ for $15 \mathrm{~min}$. The heating temperature $\left(50{ }^{\circ} \mathrm{C}\right)$ and the immersion time $(30 \mathrm{~min})$ were used according to preliminary tests, where we studied the effect of $50-60{ }^{\circ} \mathrm{C}$ for 30-60 min (data not shown). A correct selection of the couple time-temperature must be investigated since different responses can be obtained [11].

The fresh-cut process was as follows: melon fruits were peeled and cut into cubes $(2 \times 2 \mathrm{~cm})$, washed in chlorinated water ( $80 \mathrm{ppm}$ free chlorine, $13{ }^{\circ} \mathrm{C}, \mathrm{pH} 7$ for $\left.1 \mathrm{~min}\right)$, rinsed in tap water for $2 \mathrm{~min}$, and dried in ambient conditions for $5 \mathrm{~min}$ on blotting paper. Samples of approximately 20 cubes (130 g) were stored under several conditions: i) ambient air (AIR), in a glass jar to maintain high relative humidity around the samples, or ii) active modified atmosphere packaging (MAP), in trays covered with oriented polypropylene (OPP) or polylactic acid (PLA) film, and initially flushed with a gas mixture composed of $2-3 \% \mathrm{O}_{2}$ and $7-8 \% \mathrm{CO}_{2}$ before sealing. For each treatment, there were four samples (replicates), each stored at $6{ }^{\circ} \mathrm{C}$ for 11 days. Quality analyses and enzymatic activity analyses were performed at $0,2,4,7$ and 11 days of storage.

\subsection{Quality analyses}

\subsubsection{Analysis of headspace gas composition}

During storage, the headspace gas composition was determined through a silicone septum glued onto the film, in four trays per treatment. The gas composition of the packages was evaluated by quantifying $\mathrm{O}_{2}$ and $\mathrm{CO}_{2}$ concentrations using a gas analyzer (Checkmate 9900, PBI Dansensor, Ringsted, Denmark). 


\subsubsection{Sensory quality score}

Three judges scored the cubes of melons based on changes in color, visible structural integrity and odor. The visual quality score was based on the following scale [12] :

5: excellent, just sliced,

4: very good,

3: good, limit of marketability,

2: fair, limit of usability,

1: poor, inedible.

The occurrence of decay was calculated based on the amount of contaminated melon cubes and the results were expressed as a percentage.

\subsubsection{Color}

Color is one of the key factors strongly influencing visual quality and consumer acceptance. Color measurements were performed using a Konica Minolta chromameter (CR400 with a D65 light source; Minolta Camera Co., Osaka, Japan) based on the CIELAB color parameters: L* (lightness value), $a^{*}$ (redness value) and $b^{*}$ (yellowness value). The instrument was calibrated with a white ceramic plate $\left(\mathrm{L}^{*}=\right.$ 97.37; $\left.a^{*}=0.00 ; b^{*}=1.77\right)$. For each set of conditions, color measurements were obtained from 20 cubes, with one reading per cube.

\subsubsection{Soluble solid content}

Juice samples were prepared by blending and thoroughly mixing melon cubes. Soluble solids were analyzed using a Digital Hand-Held "Pocket" Refractometer PAL-1 (Atago, Tokyo, Japan) and expressed as ${ }^{\circ}$ Brix.

\subsubsection{Extraction and analysis of beta-carotene}

Following Nagata and Yamashita [13], melon fruit pulp $(0.1 \mathrm{~g})$ was extracted with $1.5 \mathrm{~mL}$ acetone:hexane (4:6). The mixture was then homogenized with a vortex and incubated at $4{ }^{\circ} \mathrm{C}$ in darkness. The homogenate was centrifuged at $15,000 \times g$ for $5 \mathrm{~min}$ at $4{ }^{\circ} \mathrm{C}$ and $200 \mu \mathrm{L}$ supernatant from each tube were placed in a 96-well plate (Nunc, Roskilde, Denmark). The absorbance was read at $\lambda=453,505,645$ and $663 \mathrm{~nm}$ in a micro-plaque reader (Power Wave HT, BioTek, Winooski, VT, USA). The concentration of beta-carotene (in $\mathrm{mg} 100 \mathrm{~mL}^{-1}$ ) was calculated as follows:

$$
\begin{aligned}
& {[\text { Beta }- \text { carotene }]=} \\
& 0.216 \mathrm{DO}_{663}-1.22 \mathrm{DO}_{645}-0.304 \mathrm{DO}_{505}+0.452 \mathrm{DO}_{453}
\end{aligned}
$$

and the results are expressed in $\mathrm{m} \mathrm{kg}^{-1}$ fresh weight (FW).

\subsection{Enzyme activities}

\subsubsection{Polyphenoloxydase activity}

Polyphenoloxydase (EC 1.10.3.1) activity (PPO) was evaluated during storage by the method of Adnan et al. [14], with slight modifications as follows: $10 \mathrm{~g}$ of melon pulp was homogenized in $20 \mathrm{~mL}$ potassium phosphate buffer at $0.2 \mathrm{M}$ (pH 6.7) and centrifuged for $10 \mathrm{~min}$ at $10,900 \times g$ at $4{ }^{\circ} \mathrm{C}$, discarding the pellet.

PPO activity was determined by mixing $1.0 \mathrm{~mL}$ enzymatic extract with $0.5 \mathrm{~mL}$ phenol solution and incubating in a water bath at $30{ }^{\circ} \mathrm{C}$ for $5 \mathrm{~min}$. The reaction was stopped by the addition of $2 \mathrm{~mL}$ ethanol $95 \%$. The absorbance was measured at $420 \mathrm{~nm}$ and the activity was expressed as mmol phenol degraded $\mathrm{kg}^{-1} \mathrm{FW} \mathrm{min}^{-1}$.

\subsubsection{Peroxidase activity}

Peroxidase (EC. 1.11.1.7) activity (POD) was evaluated during storage by the method of Lima et al. [15]. Ten grams of melon pulp were homogenized in $20 \mathrm{~mL}$ potassium phosphate buffer at $0.2 \mathrm{M}(\mathrm{pH} 6.7)$ and centrifuged for $10 \mathrm{~min}$ at $10,900 \times$ $g$ at $4{ }^{\circ} \mathrm{C}$, discarding the pellet.

POD activity was determined by mixing $0.5 \mathrm{~mL}$ enzymatic extract and $0.5 \mathrm{~mL}$ distilled water with $0.5 \mathrm{~mL}$ phenol solution and $0.5 \mathrm{~mL}$ hydrogen peroxide solution and incubating in a water bath at $30{ }^{\circ} \mathrm{C}$ for $5 \mathrm{~min}$. The reaction was stopped by addition of $2 \mathrm{~mL}$ ethanol $95 \%$. The absorbance was measured at $505 \mathrm{~nm}$ and the activity was expressed as mmol hydrogen peroxide degraded $\mathrm{kg}^{-1} \mathrm{FW} \mathrm{min}^{-1}$.

\subsection{Statistical analysis}

The experimental design was a six (conditions) $\mathrm{x}$ five (sampling dates) factorial in a completely randomized design with four replications. Analysis of variance was performed with XLSTAT software (Addinsoft, New York, USA) with the Kruskal-Wallis test, and the averages were compared by the Dunn test (without Bonferroni's correction) at a significance level of $P<0.05$.

\section{Results and discussion}

\subsection{Gas change}

Gas changes were analyzed in fresh-cut melon packaging (figure 1). The initial gas concentrations were close to the values recommended for fresh-cut melon quality maintenance [16]. During the first days, the $\mathrm{O}_{2}$ content increased and the $\mathrm{CO}_{2}$ content decreased. These changes were mainly due to gas diffusion through the film which may be higher than just the respiration rate, due to a high gas partial pressure difference. After 2 days, the $\mathrm{O}_{2}$ content was higher and the $\mathrm{CO}_{2}$ content was lower in CTRL PLA than in CTRL OPP, revealing the high PLA permeability. This is the main problem of biodegradable packaging film, which has too high a gas permeability to effectively reduce $\mathrm{O}_{2}$ and increase $\mathrm{CO}_{2}$ contents around the product. Gas concentration changes can also give information about the effect of heat treatment on the product respiration. During the first 4 days, the $\mathrm{O}_{2}$ content was lower and the $\mathrm{CO}_{2}$ content was higher in CTRL OPP than in HT OPP, and the reverse phenomenon was observed at the end of the storage. The respiration rate of fresh-cut melons was first reduced after the heat treatment and then increased. Similarly, Lamikanra 

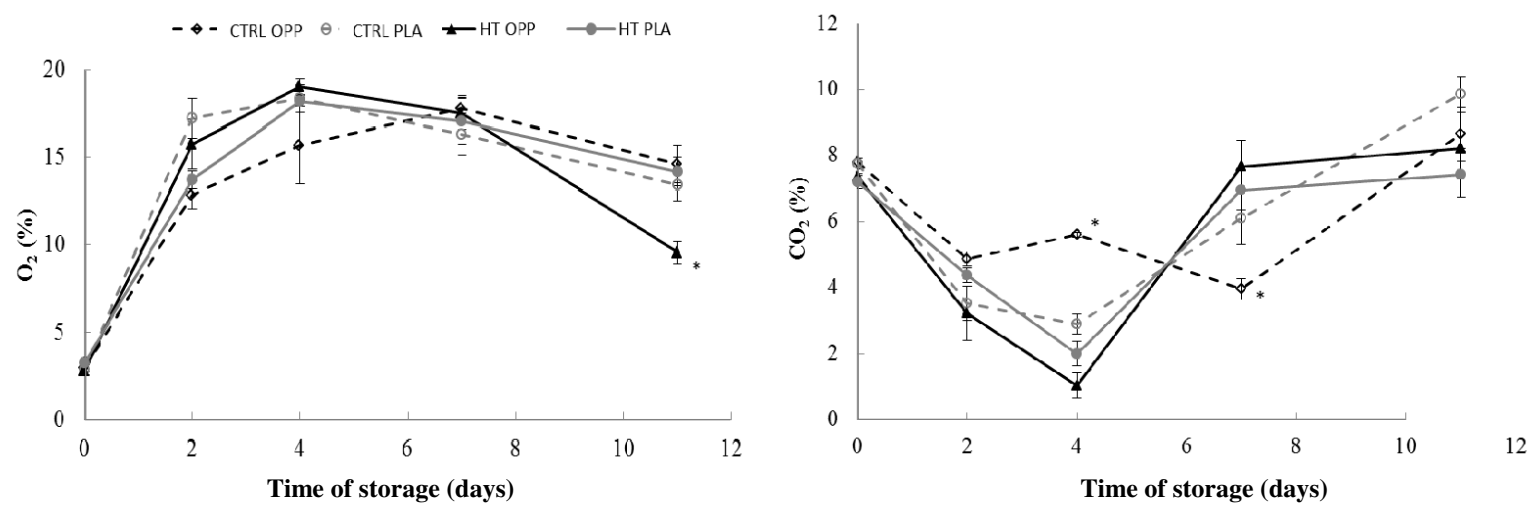

Figure 1. Oxygen and carbon dioxide changes in fresh-cut melons after heat treatment at $50{ }^{\circ} \mathrm{C}$ for 30 min (HT) or not (CTRL), and stored under active modified atmosphere packaging (MAP) with OPP or PLA films or under ambient air (AIR). Samples were stored at $6{ }^{\circ} \mathrm{C}$ for 11 days. Vertical bars represent the standard error of the mean $(n=4)$. The asterisk indicates a significant difference $(P<0.05)$ among treatments on the same day.

Table I. Decay development (in \%) of fresh-cut melons after heat treatment at $50{ }^{\circ} \mathrm{C}$ for $30 \mathrm{~min}(\mathrm{HT})$ or not (CTRL), and stored under active modified atmosphere packaging (MAP) with OPP or PLA films or under ambient air (AIR). Samples were stored at $6{ }^{\circ} \mathrm{C}$ for 11 days.

\begin{tabular}{lccccccc}
\hline \multirow{2}{*}{$\begin{array}{l}\text { Days } \\
\text { of storage }\end{array}$} & \multicolumn{3}{c}{ Control treatment (CLTR) } & & \multicolumn{3}{c}{ Heat treatment (HT) } \\
\cline { 2 - 4 } \cline { 7 - 8 } & OPP & PLA & AIR & & OPP & PLA & AIR \\
\hline 0 & 0.00 & 0.00 & 0.00 & & 0.00 & 0.00 & 0.00 \\
2 & 0.00 & 0.00 & 0.00 & & 0.00 & 0.00 & 0.00 \\
4 & 0.00 & 0.00 & 0.00 & & 0.00 & 0.00 & 0.00 \\
7 & 38.75 & 18.75 & 71.25 & & 0.00 & 13.75 & 0.00 \\
11 & 72.50 & 27.50 & 77.50 & & 5.00 & 18.75 & 57.50 \\
\hline
\end{tabular}

et al. [10] and Silveira et al. [17] observed a decreasing respiration rate in fresh-cut melons after a heat treatment of $50{ }^{\circ} \mathrm{C}$ for $60 \mathrm{~min}$ and $60{ }^{\circ} \mathrm{C}$ for $120 \mathrm{~s}$, respectively.

Heat treatments performed in non-lethal conditions cause a moderate stress when applied to fruit tissues, which causes a temporary stop of the normal metabolism, that recovers once the fruit returns to non-stressful temperatures [18]. This could explain the observed reduction of respiration after the heat treatment. At the end of the storage, microbial growth or senescence could be responsible for the respiration increase.

\subsection{Sensory analysis}

Appearance is a major criterion for determining the acceptability of products and is currently used as an indicator of freshness and quality in fresh-cut research and industry [19]. The decay development increased during storage (table I). After 7 days, the occurrence of decay was higher in all control samples than in heat-treated samples. Moreover, the HT OPP treatment was the best for significantly reducing decay development throughout the storage period. Heat treatments have been validated by many countries as viable non-chemical disinfestation treatments [20]. Thus, heat treatments could be a step to enhance food safety, as MAP may not fully guarantee microbial safety [21].

The visual quality scores decreased during the storage for all conditions (figure 2). After 7 days (date limit of

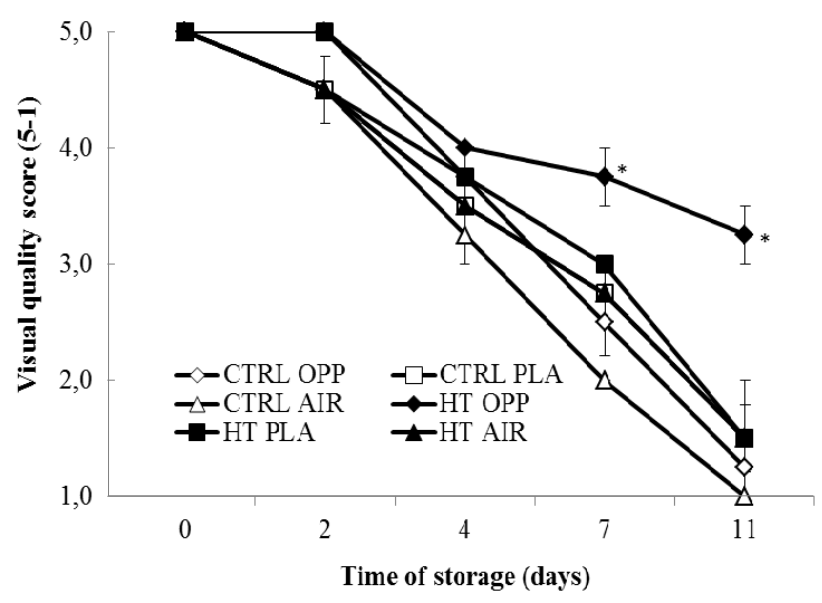

Figure 2. Visual quality scores of fresh-cut melons after heat treatment at $50{ }^{\circ} \mathrm{C}$ for $30 \mathrm{~min}$ (HT) or not (CTRL), and stored under active modified atmosphere packaging (MAP) with OPP or PLA films or under ambient air (AIR). Samples were stored at $6{ }^{\circ} \mathrm{C}$ for 11 days. Vertical bars represent the standard error of the mean $(n=4)$. The asterisk indicates a significant difference $(P<0.05)$ among treatments on the same day.

consumption), the visual quality score of CTRL AIR was the lowest, 2.00 (fair and limit of usability). Then the scores were 2.50 for CTRL OPP, around 2.75 for both CTRL PLA and HT AIR, and 3.00 (good and limit of marketability) for HT PLA. The score for HT OPP was significantly higher after 7 days (3.75), but also throughout the storage period. This result was correlated with the low decay development in HT OPP samples. The positive effect of heat treatment on the visual quality score was previously observed. For instance, Djioua et al. [12] found that the same heat treatment, $50^{\circ} \mathrm{C}$ for $30 \mathrm{~min}$, improved the visual quality of fresh-cut 'Keitt' mangoes for up to 6 days at $6{ }^{\circ} \mathrm{C}$. Regarding the impact of MAP, Oliveira et al. [22] observed that active MAP composed of $5 \% \mathrm{O}_{2}$ with $5 \% \mathrm{CO}_{2}$ and $2 \% \mathrm{O}_{2}$ with $10 \% \mathrm{CO}_{2}$ was effective at maintaining the quality and flavor attributes of fresh-cut 'Orange Flesh' melon. In this study, the combination of the heat treatment and active MAP with OPP film significantly improved both 

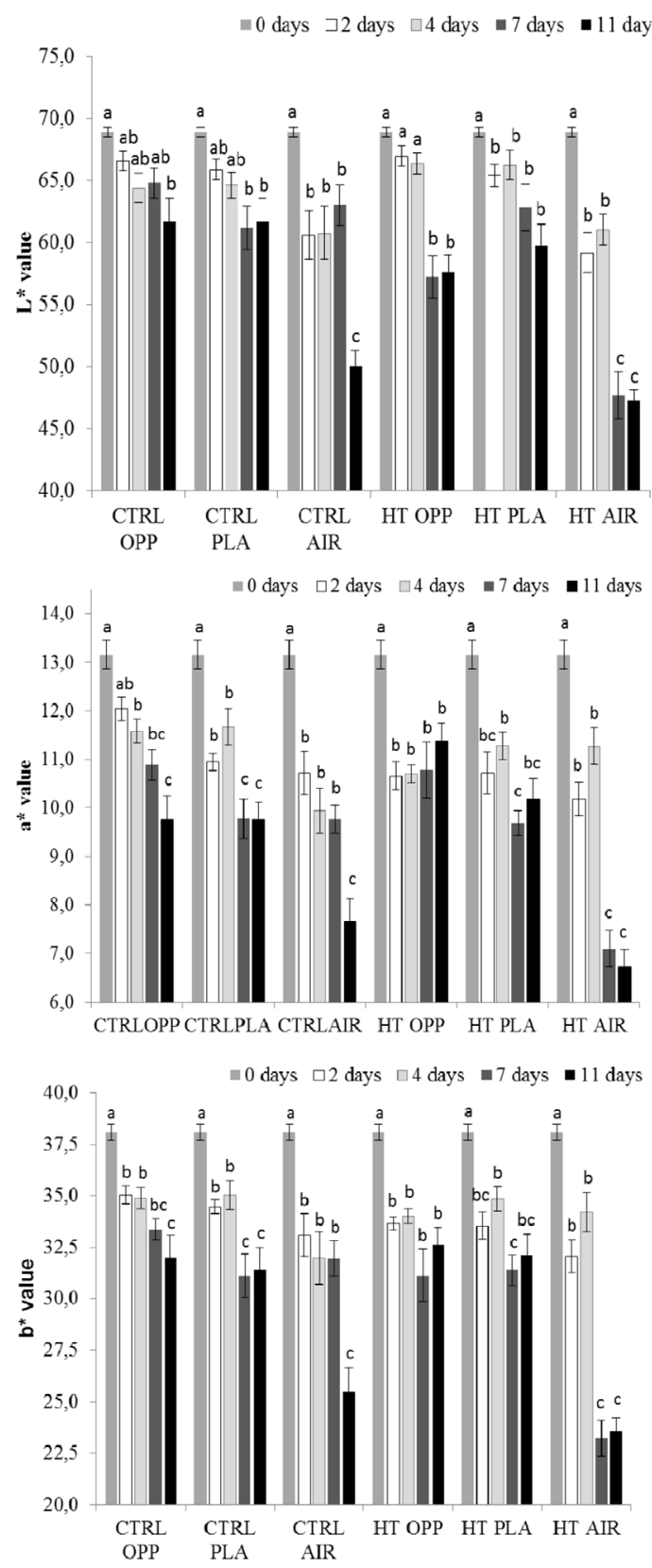

Figure 3. Color change ( $\mathrm{L}^{*}, \mathrm{a}^{*}$ and $\mathrm{b}^{*}$ values) of fresh-cut melons after heat treatment at $50{ }^{\circ} \mathrm{C}$ for $30 \mathrm{~min}$ (HT) or not (CTRL), and stored under active modified atmosphere packaging (MAP) with OPP or PLA films or under ambient air (AIR). Samples were stored at $6{ }^{\circ} \mathrm{C}$ for 11 days. Vertical bars represent the standard error of the mean $(n=20)$ with mean separation by Dunn $(P<0.05)$.

the decay development and the visual quality of 'Charentais' melons for up to 11 days.

The color was analyzed by the $\mathrm{L}^{*}, \mathrm{a}^{*}, \mathrm{~b}^{*}$ system. After the first day, a significant decrease was observed for both $a^{*}$ and $\mathrm{b}^{*}$ values in all conditions (figure 3 ). The fresh-cut processing, which is very harmful for products, could explain this quick decrease. At the end of the storage, high color losses were observed for samples stored in the air. The decrease in $a^{*}$ values was $42 \%$ and $49 \%$ and that in $b^{*}$ values was $33 \%$ and $38 \%$ for
Table II. Soluble solid contents (in ${ }^{\circ}$ Brix) of the juice of fresh-cut melons after heat treatment at $50{ }^{\circ} \mathrm{C}$ for $30 \mathrm{~min}$ (HT) or not (CTRL), and stored under active modified atmosphere packaging (MAP) with OPP or PLA films or under ambient air (AIR). Samples were stored at $6{ }^{\circ} \mathrm{C}$ for 11 days. Data are means $(n=4) \pm$ standard error with mean separation by Dunn $(P<0.05)$.

\begin{tabular}{lcc}
\hline Treatments & Day 0 & Day 11 \\
\hline CTRL OPP & & $6.95 \pm 0.39$ \\
CTRL PLA & & $6.68 \pm 0.55$ \\
CTRL AIR & $6.50 \pm 0.43$ & $6.58 \pm 0.31$ \\
HT OPP & & $7.78 \pm 0.26$ \\
HT PLA & & $7.98 \pm 0.87$ \\
HT AIR & & $6.50 \pm 0.41$ \\
\hline
\end{tabular}

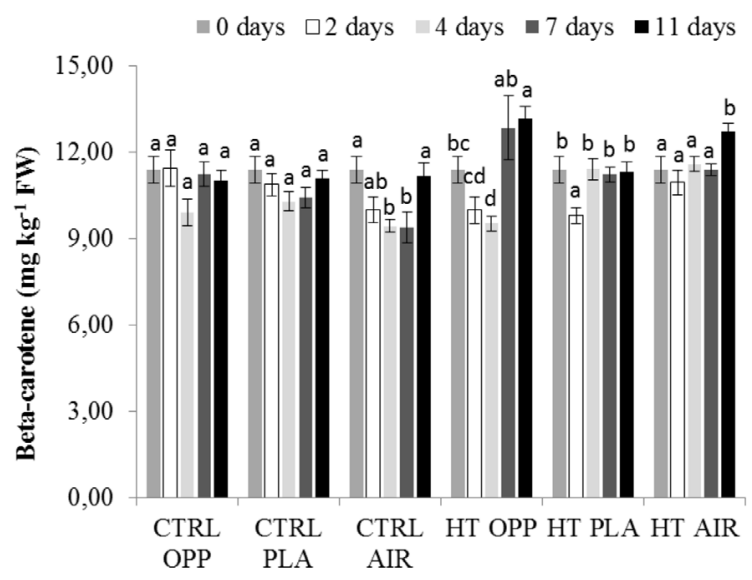

Figure 4. Beta-carotene contents of fresh-cut melons after heat treatment at $50{ }^{\circ} \mathrm{C}$ for $30 \mathrm{~min}(\mathrm{HT})$ or not (CTRL), and stored under active modified atmosphere packaging (MAP) with OPP or PLA films or under ambient air (AIR). Samples were stored at $6{ }^{\circ} \mathrm{C}$ for 11 days. Data are means $(n=4) \pm$ standard error with mean separation by Dunn $(P<0.05)$.

CTRL AIR and HT AIR, respectively. HT OPP was the only treatment that significantly maintained $\mathrm{a}^{*}$ and $\mathrm{b}^{*}$ values from day 2 to day 11. HT PLA was the second treatment that slowed down the decrease in these values. These results demonstrate the negative impact of storage in the air for fresh-cut melon. This study also highlights the impact of combining MAP and heat treatment to maintain the pulp color.

For $\mathrm{L}^{*}$ values, a decrease was observed in samples stored in the air and samples that were heat-treated. Several authors also observed a decrease in $\mathrm{L}^{*}$ when fresh-cut products are subjected to hot water treatment, such as mango [12] or apple [23]. The heat treatment could induce a loss of brightness that cannot be detected visually and that is not correlated with the pulp color.

\subsection{Soluble solids}

During storage, no significant changes were found in the soluble solid contents among treatments (table II). There is generally no significant effect of heat treatment, either water or hot air, on soluble solids [18]. 

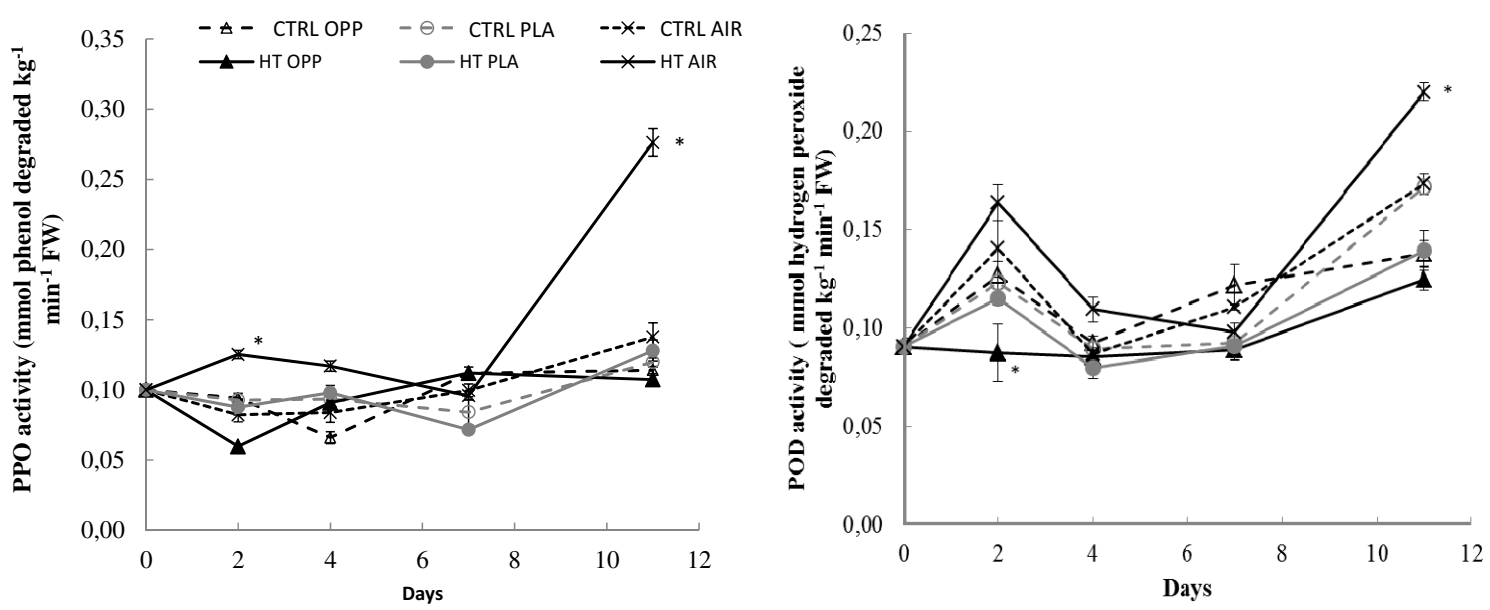

Figure 5. Enzyme activity changes of PPO (polyphenoloxidase) and POD (peroxidase) of fresh-cut melons after heat treatment at $50{ }^{\circ} \mathrm{C}$ for 30 min (HT) or not (CTRL), and stored under active modified atmosphere packaging (MAP) with OPP or PLA films or under ambient air (AIR). Samples were stored at $6{ }^{\circ} \mathrm{C}$ for 11 days. Data are means $(n=4) \pm$ standard error with mean separation by Dunn $(P<0.05)$. The asterisk indicates a significant difference among treatments for the same day.

\subsection{Beta-carotene}

Melon's antioxidant properties are mainly due to its high amounts of beta carotenoids. During the storage, the betacarotene content remained stable in all control samples whatever the packaging conditions (figure 4). When samples were heat-treated, the beta-carotene content increased after 4 days in HT PLA, after 7 days in HT OPP, and only after 11 days in HT AIR. It has been reported that heat treatment, applied as heat shock, may trigger a defense response that can improve post-harvest quality and antioxidants which are directly connected to this defense [24]. The high carotenoid levels in HT OPP and HT PLA samples could have induced the lower decay development.

\subsection{Enzyme analysis}

The activity of two enzymes involved in the browning process of fruits, PPO and POD, was monitored over the storage period. After 2 and 11 days of storage, PPO and POD activities were the highest in HT AIR (figure 5). A de novo synthesis of PPO could be suggested as a response to stress, such as reported by Espin et al. [25], who observed that wounding led to an exponential increase in PPO activity due to the activation of a latent form of PPO by newly formed proteases. This result can be correlated with the high browning process that appeared in our samples stored in the air. Conversely, the melon samples that had a high visual quality score, under the HT OPP treatment, had a reduced activity of PPO and POD after 2 days of storage. The inactivating process of heat treatment on various thermal enzyme activities such as PPO or PAL has already been reported [25]. Sometimes, however, the observations were contradictory, such as those reported by Maghoumi et al. [26], who showed that heat treatment $\left(55^{\circ} \mathrm{C}\right.$ for $\left.30 \mathrm{~s}\right)$ suppressed PPO activity and increased POD activity in freshcut pomegranate. The impact of heat treatment on fruit enzyme activity can therefore change between products and seems to be transient.

\section{Conclusion}

Few studies have examined the associated effect of modified atmosphere packaging (MAP) and physical treatment. This study demonstrated that combining active MAP with heat treatment at $50{ }^{\circ} \mathrm{C}$ for $30 \mathrm{~min}$ applied to whole fruit significantly reduced the visual browning and decay development and increased the beta-carotene content of fresh-cut melon. Heat treatment is suggested as a safe and easy opportunity to extend the shelf life and improve the sensorial attributes of fresh-cut melon stored under MAP.

Acknowledgements. The authors are thankful to Campus France for an Eiffel grant for Cristiane Maria Ascari Morgado to work in France.

\section{References}

[1] Moreira S.R., Melo A.M.T. de Purquerio L.F.V., Trani P.E., Narita N., Melão (Cucumis melo L.). Infobibos (2009) http://www.infobibos.com/Artigos/2009_3/melao/index.htm, accessed: 20/12/2013.

[2] Aguayo E., Escalona V.H., Artés F., Metabolic behavior and quality changes of whole and fresh processed melon, J. Food Sci. 69 (2004) 148-155.

[3] Conte A., Scrocoo C., Brescia I., Del Nobile M.A., Different packaging strategies for fresh-cut 'barattiere' melon cultivar (Cucumis melo L.), Int. J. Food Sci. Technol. 44 (2009) 1422-1428.

[4] Fallik E., Prestorage hot water treatments (immersion, rinsing and brushing), Postharvest Biol. Technol. 32 (2004) 125-134.

[5] Klein J.D., Lurie S., Pre-storage heat treatment as a means of improving poststorage quality of apples, J. Am. Soc. Hort. Sci. 115 (1990) 265-269.

[6] Civello P.M., Martinez G.A., Añón M.C., Heat treatments delay ripening and post-harvest decay of strawberry fruit, J. Agric. Food Chem. 45 (1997) 4589-4594.

[7] Porat R., Pavoncello D., Peretz J., Ben-yehoshua A.S., Lurie S., Effects of various heat treatments on the induction of cold tolerance and the postharvest qualities of 'Star Ruby Grapefruit', Postharvest Biol. Technol. 18 (2000) 159-165. 
[8] Benitez M.M., Acedo A.L. Jr, Jitareerat P., Kanlayanarat S., Mango fruit softening response to postharvest heat treatment, Acta Hort. 712 (2006) 811-816.

[9] Teitel D.C., Barkai-Golan R., Aharoni Y., Copel Z., Davidson H., Toward a practical, postharvest heat treatment for 'Galia' melons, Sci. Hort. 45 (1991) 339-344.

[10] Lamikanra O., Bett-garber K., Ingram D., Watson M., Use of mild heat pretreatment for quality retention of fresh-cut cantaloupe melon, J. Food Sci. 70 (2005) 53-57.

[11] Thai T.H., Hien D.M., Self G., Ducamp M.N., Effects of hot air treatment on postharvest quality of 'cat Hoa loc' mangoes, Fruits 65 (2010) 237-244.

[12] Djioua T., Charles F., Lopez-Lauri F., Filgueiras H., Coudret A., Freire Junior M., Ducamp-Collin M.N., Sallanon H., Improving the storage of minimally processed mangoes (Mangifera indica L.) by hot water treatments, Postharvest Biol. Technol. 52 (2009) 221-226.

[13] Nagata M., Yamashita I., Simple method for simultaneous determination of chlorophyll and carotenoids in tomato fruit, J. Jpn Soc. Food Sci. 39 (1992) 925-928.

[14] Adnan T.A.B.T., Augustin M.A, Ghazali H.M., Polyphenoloxidase from starfruit (Averrhoa carambola L.), Pertanika J. Trop. Agric. Sci. 9 (2) (1986) 219-224.

[15] Lima G.P.P., Brasil O.G., Oliveira A.M. de., Poliaminas e atividade da peroxidase em feijão (Phaseolus vulgaris L.) cultivado sob ambiente salino, Sci. Agric. 56 (1) (1999) 21-26.

[16] Bai J., Saftner R.A., Watada A.E., Characteristics of freshcut honeydew (Cucumis xmelo L.) available to processors in winter and summer and its quality maintenance by modified atmosphere packaging, Postharvest Biol. Technol. 28 (2003) 349-359.

[17] Silveira A.C., Aguayo E., Escalona V.H., Artés F., Hot water treatment and peracetic acid to maintain fresh-cut Galia melon quality, Innov. Food Sci. Emerg. Technol. 12 (2011) 569-576.
[18] Paull R.E., Jung Chen N., Heat treatment and fruit ripening, Postharvest Biol. Technol. 21 (2000) 21-37.

[19] Cantwell M.I., Suslow T.V., Postharvest handling systems: fresh-cut fruits and vegetables, in: Kader A.A. (Ed.), Postharvest technology of horticultural crops, University of California, Davis, 2002, pp. 445-463.

[20] Jacobi K.K., MacRae E.A., Hetherington S.E., Postharvest heat disinfestation treatments of mango fruit, Sci Hort. 89 (4) (2001) 171-193.

[21] Oliveira M., Abadias M., Usall J., Torres R., Teixido N., Vinas I., Application of modified atmosphere packaging as a safety approach to fresh-cut fruits and vegetables - A review, Trends Food Sci. Technol. 46 (2015) 13-26.

[22] Araújo F.M.M.C. de, Machado A.V., Chitarra A.B., Effect of the active modified atmosphere in the quality of the melon orange flesh processed minimally, Ciênc. Agrotec. 29 (4) (2005) 817-823.

[23] Aguayo E., Requejo-Jackman C., Stanley R., Woolf A., Hot water treatment in combination with calcium ascorbate dips increases bioactive compounds and helps to maintain fresh-cut apple quality, Postharvest Biol. Technol. 110 (2015) 158-165.

[24] Salman A., Goupil P., Filgueras H., Charles F., Ledoigt G., Sallanon H., Controlled atmosphere and heat shock affect PAL1 and HSP90 mRNA accumulation in fresh-cut endive (Cichorium intybus L.), Eur. Food Res. Technol. 227 (2008) 721-726.

[25] Espin J.C., Van Leeuwen J., Wichers H.J., Kinetic study of the activation process of a latent mushroom (Agaricus bisporus) tyrosinase by serine proteases, J. Agr. Food Chem. 47 (1999) 3509-3517.

[26] Maghoumi M., Gómez P.A., Mostofi Y., Zamani Z., ArtésHernández F., Artés F., Combined effect of heat treatment, UV-C and superatmospheric oxygen packing on phenolics and browning related enzymes of fresh-cut pomegranate arils, Food Sci. Technol. 54 (2013) 389-396. 